\title{
The Role of Out-of-Class Communication in Instructor's Verbal/Non-Verbal Behavior, Trust, and Student Motivation
}

\begin{abstract}
Shahnawaz Khan ${ }^{1}$, Attaullah Shah ${ }^{2}$, Salman Ahmad ${ }^{3}$
Abstract

The role of out-of-class communication among teachers and students has long been a question of great interest in the literature. Research has shown that students that engage in out-of-class-communication with their teachers perform better in their academic career. This paper investigates the relationship between students-teachers' out-of-class communication and trust, motivation, and teachers' immediacy. For this purpose a sample of 204 students were asked to fill up questionnaires regarding their experience with their teachers. The results show that out-of-class communication is positively correlated to a teacher's verbal and non-verbal immediacy, trust, and students' motivation.
\end{abstract}

\section{Introduction}

Economic recession, increasing rate of inflation coupled with a rapid growth of higher education institutions in a very short span of time has made it difficult for every higher education institution in Pakistan to grab a higher market share as far as the students are concerned. Every university and institution is facing difficulty in raising funds for self-sustenance and for decreasing its dependence on government funds which are unfortunately never enough for the universities/institutes. Attracting more and more students and retaining the existing ones becomes a challenge to these higher education institutions.

The question that arises here is how such universities/institutes should achieve students retention. Research has shown that students' retention is greatly affected by the teachers' immediate behaviors towards their students, and especially their out-of-class-communication (OCC) with the students is highly correlated with students' motivation and their retention (Jones, 2008). It is found that the teacher's verbal and non-verbal behavior in the class room determines the level and frequency of out-of-class-communication, which helps building trust and motivation among the students (Dobransky \& Frymier, 2004). Further, students that engage in out-of-class-communication with their teachers perform better in their academic career (Milem \& Berger, 1997) because of the high motivational level and trust in their teachers. This

1 Assistant Professor, Institute of Management Sciences, Peshawar.

2 Assistant Professor, Institute of Management Sciences, Peshawar.

3 Assistant Professor, Institute of Management Sciences, Peshawar. 
results in reduced dropout ratio because of their improved academic performance and higher student retention (Witt, Schrodt, \& Turman, 2010).

This study, therefore, is of strategic importance as it will help determine if the same relationship exists between the teacher's out-of-class-communication with his/her student's level of motivation and trust in former. The significance of the study is that it will test the said relationship within a different contextual background. The results, if found the same, will not only validate the relationship but also help universities/ institutions in Khyber Pakhtunkhwa in devising effective strategies in order to cope with the challenge of students retention and self-sustenance.

\section{Literature Review}

It has been found that in addition to formal communication with the students inside the classes, instructor's informal communication with students outside the class sessions helps improve the relationship between the students and faculty (Pascarella \& Terenzini, 1991; Nora \& Cabrera, 1996; Milem \& Berger, 1997; Pike, Schroeder, \& Berry, 1997; Jaasma \& Koper, 1999; Pogue \& Ahyun, 2006; Jones, 2008). The students get a chance of sharing their issues and problems with the faculty members and thus feel more valued and motivated (Kuh, 1995). A number of researches that have been carried out in this regard found that there is a positive relationship between the student retention and out-of-class-communication between the students and faculty (Jaasma \& Copper, 1999; Lau, 2003). Thus out-of-class-communication not only helps in the overall retention of students for higher education institutions but also bring benefits to students and faculty as well (Nadler \& Nadler, 2000). Understanding the significance of out-of-class-communication is therefore important due to the benefits it brings to higher education institutions, students, and faculty. A number of studies conducted on out-of-class-communication found that the students' out-of-class-communication with faculty helped students better understand their academic courses and build their cognitive abilities (Terenzini, Pascarella, \& Blimling, 1996; Jones, 2008), motivate them towards achieving a higher qualification (Pascarella \& Terenzini, 1991), to become more confident (Kuh, 1995), feel valued, and perform better in their academics than those students who did not involve in out-of-class-communication with their faculty (Milem \& Berger, 1997). Students involved in out-of-class-communication with the faculty enjoyed their stay at the institute and cherished their experience than those who did not involve in such communication (Jones, 2008). As mentioned earlier, out-of-class-communication also brought benefits to the faculty members in a way that they were ranked high in their class performance (Lamport, 1993). The teachers who were involved in out-of-class-communication had higher evaluations than those who were not involved in such communication (Jaasma \& Koper, 1999). 
Despite the benefits that out-of-class-communication offer to students and teachers, very little attention has been given to the topic (Nadler \& Nadler, 1995; Fusani, 1994). Further, a number of researches have indicated that teachers generally have the tendency to avoid out-of-class-communication with their students. They believe that their duty is only concerned with class teaching, and tend to avoid the responsibility outside their class rooms (Cotten \& Wilson, 2006). According to one of the researches, $23 \%$ of the students surveyed have never met their teachers other than their class sessions; therefore, they had no informal meeting with their teachers; $50 \%$ of the students had two or fewer contacts with their teachers (Jaasma $\&$ Koper, 1999), and also the length of their informal meetings were substantially shorter than desired (Wilson, Woods, \& Gaff, 1974; Theophilides \& Terenzini, 1981). It has been found that most of the out-of-class-communication usually involves discussion regarding the course (Fusani, 1994). Students' discussion regarding their course during out-of-class-communication has a positive impact on their decision to remain associated with the institute (Pascarella \& Terenzini, 1979). Students tend to remain loyal to the institute when they feel they are valued and been taken care of by the teachers. In addition, it also has a favorable impact on students' academic performance (Pascarella \& Terenzini, 1978).

There is a close relationship between a teacher's attitude inside classroom and his/her out-of-class-communication with the students (Fusani, 1994; Dallimore, 1995; Wilson et al., 1974). The teacher's verbal and non-verbal behavior within the classroom determines his out of class relationship with students (Nadler \& Nadler, 1995; Dobransky \& Frymier, 2004). A teacher's polite, helping, and welcoming behavior (verbal and non-verbal) inside the class room encourages students to engage in out-of-class-communication (Aylor \& Oppliger, 2003). On the other hand a teacher's rude and unwelcoming gestures, be them verbal or non-verbal, discourage students to engage in out-of-class-communication with their teacher (Myers, Edwards, Wahl, \& Martin, 2007). A number of researches on the relationship between verbal immediacy and out-of-class-communication found that the two were positively correlated (Fusani, 1994; Myers \& Knox, 2001). Verbal immediacy was found to enhance student's motivation and satisfaction of out-of-class-communication (Christophel, 1990; Richmond, 1990). Thus, it can be inferred that teacher's immediacy enhances student's motivation towards learning (Witt et al., 2010). Since teacher's immediacy behavior enhances student's motivation and that there is an expected positive relationship between teacher's immediacy behavior and out-of-class-communication, it can then be inferred that there will also be a positive relationship between student motivation and out-of-class-communication.

As a result of the above prediction, if we further probe into the student teacher 
relationship, it can be inferred that a student will tend to have more individualized trust in a teacher with whom he/she is engaged in out-of-class-communication (Nadler $\&$ Nadler, 1995, 2000). This means that there is a positive relationship between teacher's behavior and individualized trust (Jaasma \& Koper, 1999). If a teacher exhibits good behavior, the student will engage in more out-of-class-communication and will have high individualized trust in that teacher (Dobransky \& Frymier, 2004). On the other hand, if a teacher exhibits unwelcoming behavior, the student will not engage in out-of-class-communication and will have no individualized trust in that teacher. It can then logically be concluded that there is a positive relationship between the student's perception of trust in his/her teacher and out-of-class-communication with the latter. The more trust students have in their teacher, the more will they engage in out-of-class-communication.

Based on above inferences, the study presents its following theoretical framework:

\subsection{Theoretical Framework}

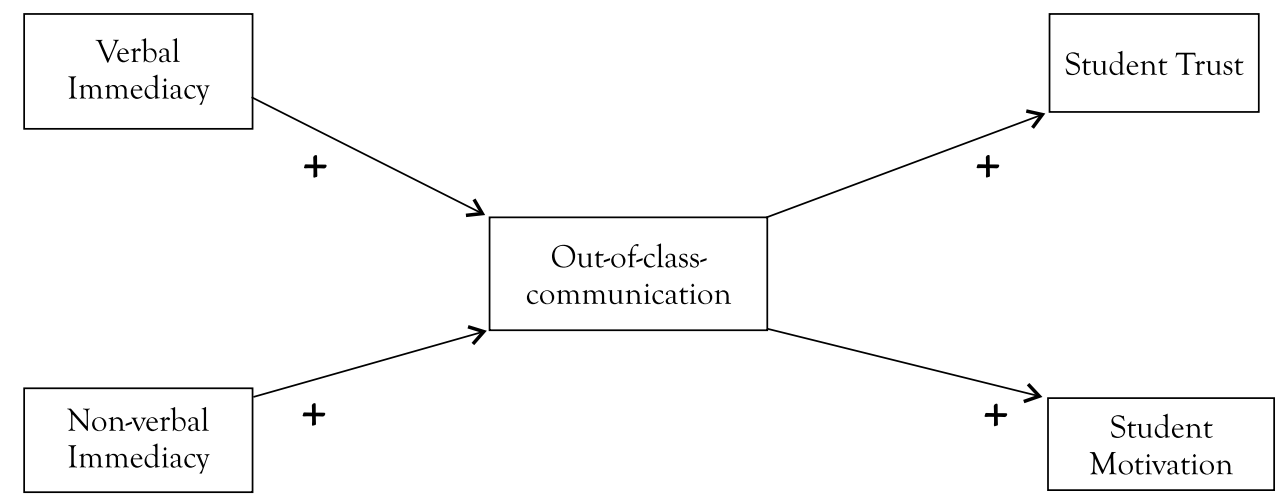

\subsection{Research Questions}

$\mathrm{Q}_{1}$ : What is the nature of OCC in terms of frequency, length, content, and student satisfaction?

$\mathrm{Q}_{2}$ : Is there any relationship between students' perceptions regarding instructor's verbal and non-verbal immediacy and OCC?

$\mathrm{Q}_{3}$ : Is there a relationship between students' perceptions of trust in teacher and OCC?

$\mathrm{Q}_{4}$ : Is there a relationship between student motivation and OCC? 


\section{Methodology}

\subsection{Unit of Analysis}

As the study is about investigating the student teacher relationship in the context of out-of-class-communication and its impact on trust and motivation of students, the main focus of data collection were students. The unit of analysis was therefore individual students of the Institute of Management Sciences, Peshawar.

\subsection{Sample}

The rationale for choosing the Institute of Management Sciences was that the researchers had an access to the students at this institute and was therefore convenient to collect data for research. The study has used stratified random sampling for drawing samples from the population. The sample included respondents from different undergraduate and graduate programs, and were mostly in their terminal semesters. The sample comprised of 204 students from the Institute of Management Sciences, Khyber Pakhtunkhwa, of which 160 were male and 44 were female students. Out of 204 students 40 students were MBA students, who were in their third semester and out of those 40 students 20 were specializing in the area of finance, 11 were specializing in the area of HRM and the remaining 9 were marketing students. Similarly, 100 out of the 204 students were from the undergraduate program (BBA). Out of these 100 students, 50 were in the second last semester of their degree, whereas the remaining fifty were in their fifth semester. Out of 50 students from the second last semester, 13 were specializing in IT, 25 were specializing in finance, 5 were specializing in marketing and the remaining 7 were HR students. In the same way, out of 50 students from the fifth semester, 30 were in finance, 7 were from IT, 7 were from marketing and 6 were from HR. 40 of the remaining 64 students were doing their masters in Development Studies, whereas the 24 students were the MSc Applied Economics graduates.

The sampled students were from diverse backgrounds covering a wide geographical range of Khyber Pakhtunkhwa (KPK). The pool of sample included students from Sawabi, Mardan, Charsadda, Karak, Kohat, Swat, Dir, Malakand, Chitral and the tribal belt including Bajaur Agency, Mohmand Agency, and North Waziristan.

In order to get an unbiased and useful response from the sample, the chosen students were the ones who were in the final stages of their semesters. This means they had spent a substantial amount of time with their instructors they were about to evaluate. Further, because the students came from a number of different programs and areas of specialization, they were asked to evaluate those teachers with whom they were taking their specialization subjects and to evaluate the instructors with 
whom they just attended a class before filling up the questionnaire. This approach was adopted with the intention to evaluate as many teachers as possible and to evaluate teachers from different areas of specialization so that the data is collected on a broader platform. Also, as students came from various undergraduate and graduate programs, there was a significant variation in their ages, ranging from 19 years to 37 years. The data collected from such a wide range as far as the age is concerned helped grasp a broader understanding of the area under investigation.

\subsection{Scales used for data collection}

The tool used for data collection was self-administered questionnaire. Based on the literature review and theoretical framework, five variables are identified for investigation which are out-of-class-communication (OCC), trust, motivation, and teacher immediacy that included the verbal and non-verbal behavior of teacher in the class. Since there existed an established and reliable scales for the measurement of such variables therefore, those scales were utilized for data collection. Table 1 further elaborate details regarding the measurement scales. The questionnaire has used a seven point Likert scale for measuring student's motivation and trust, whereas a five point Likert scale is used for measuring the instructor's verbal and non-verbal behavior. As far as OCC is concerned, the items were measured on three scales i.e.

Table 1: Study Variables and their Measurement Scales

\begin{tabular}{|c|c|c|}
\hline Variable & Measurement Scale & Source \\
\hline Motivation & Student Motivation Scale (SMS) & $\begin{array}{c}\text { Rubin, Palmgreen, \& Sypher } \\
\text { (1994) }\end{array}$ \\
\hline Trust & Individualized Trust Scale (ITS) & Wheeless \& Grotz (1977) \\
\hline Non-Verbal Immediacy & $\begin{array}{c}\text { Revised Non-Verbal Immediacy } \\
\text { Measure (RNIM) }\end{array}$ & $\begin{array}{l}\text { McCroskey, Sallinen, Fayer, } \\
\text { Richmond, \& Barraclough } \\
\text { (1996) }\end{array}$ \\
\hline Verbal Immediacy & $\begin{array}{l}\text { Verbal Immediacy Behaviors } \\
\text { (VIB) }\end{array}$ & Gorham (1998) \\
\hline Out-of-class-communication & $\begin{array}{l}\text { Frequency, content, length and } \\
\text { satisfaction with OCC }\end{array}$ & Jaasma \& Koper (1999) \\
\hline
\end{tabular}

numbers, minutes and percentages. The questionnaire used for data collection is provided in Appendix.

The reliabilities of scales using Cronbach's alpha are as follows: SMS, alpha $=$ .92; ITS, alpha $=.91 ;$ RNIM, alpha $=.89 ;$ and VIB, alpha $=.89$

Pearson's correlation coefficient test was applied to check for the strength of 
relationship between out-of-class-communication, trust, motivation, verbal immediacy and non-verbal immediacy. Further, descriptive statistics are shown to check the frequency, content, length and satisfaction of out-of-class-communication.

\subsection{Model}

The study uses regression to quantify the dependence of dependent variables over independent variables. The model used for this purpose is Seemingly Unrelated Model (SUR). The rationale behind the use of SUR model is that it is expected that the error terms of both the equation of the model are interlinked. Following are the equations used in the model,

Table 2: Descriptive Statistics (Variable of Interest)

\begin{tabular}{|c|c|c|c|c|c|}
\hline & N & Minimum & Maximum & Mean & Std. Deviation \\
\hline Motivation & 204 & 16.00 & 70.00 & 35.0147 & 13.23098 \\
\hline Trust & 204 & 15.00 & 98.00 & 25.5294 & 15.77752 \\
\hline Verbal & 204 & 23.00 & 62.00 & 43.1912 & 9.14189 \\
\hline NV & 204 & 9.00 & 35.00 & 24.2990 & 4.89433 \\
\hline OCC & 204 & 1.00 & 465.00 & 133.1078 & 119.13737 \\
\hline
\end{tabular}

Trust $=\alpha_{11}+\alpha 1_{2}$ non_ver $b+\alpha_{13}$ verb $+\alpha_{14}$ occ $+\varepsilon_{1}$

Motivation $=\alpha_{21}+\alpha_{22}$ non_verb $+\alpha_{23}$ verb $+\alpha_{24}$ occ $+\varepsilon_{2}$

\section{Data Analysis}

Table 2 shows the minimum and maximum scores for variables of interest. Minimum score in case of students motivation is 16 whereas the maximum score is 70 with a mean value of 35 , minimum score for trust is 15 and maximum score is 98 with a mean value of 26 , minimum score for verbal immediacy is 23 and maximum score is 62 with a mean score of 43 , minimum score for non-verbal immediacy is 9 and maximum score is 35 with a mean score of 24 , and similarly minimum score for out-of-class-communication is 1 and maximum score is 465 with a mean value of 119 .

Table 3 shows various aspects of out-of-class-communication. The results show that the minimum number of office visits by the sampled students were recorded to be 0 whereas the maximum number of office visits were 10 with a mean value of 1.3, which shows that the average number of students have visited the offices of their teacher for less than two times. Similarly, the minimum number of informal contact, i.e. other than the classroom and office visits by the students with their teachers were 
Table 3: Descriptive Statistics (Out of Class Communication)

\begin{tabular}{|c|c|c|c|c|c|}
\hline $\begin{array}{c}\text { Frequency of office } \\
\text { visits }\end{array}$ & 204 & .00 & 10.00 & 1.2549 & 1.95358 \\
\hline $\begin{array}{c}\text { Frequency of infor- } \\
\text { mal contact }\end{array}$ & 204 & .00 & 9.00 & 1.8382 & 2.43503 \\
\hline Length of office visits & 204 & .00 & 40.00 & 5.1078 & 9.02422 \\
\hline $\begin{array}{c}\text { Length of informal } \\
\text { contacts }\end{array}$ & 204 & .00 & 90.00 & 10.8333 & 21.97808 \\
\hline $\begin{array}{c}\text { Discuss course work } \\
\text { during office visits }\end{array}$ & 204 & .00 & 100.00 & 25.6127 & 36.22034 \\
\hline $\begin{array}{c}\text { Discuss course work } \\
\text { during informal } \\
\text { contact }\end{array}$ & 204 & .00 & 92.00 & 24.0392 & 32.98064 \\
\hline $\begin{array}{c}\text { Discuss personal } \\
\text { problems during } \\
\text { office visits }\end{array}$ & 204 & .00 & 80.00 & 4.1176 & 13.07635 \\
\hline $\begin{array}{c}\text { Discuss personal } \\
\text { problems during } \\
\text { informal contact }\end{array}$ & 204 & .00 & 90.00 & 9.2892 & 18.62409 \\
\hline $\begin{array}{c}\text { Socialize during } \\
\text { office visits }\end{array}$ & 204 & .00 & 100.00 & 21.7647 & 34.11547 \\
\hline $\begin{array}{c}\text { Socialize during in } \\
\text { informal contact }\end{array}$ & 204 & .00 & 100.00 & 24.5833 & 34.39051 \\
\hline Student satisfaction & 204 & 1.00 & 7.00 & 4.6667 & 2.10012 \\
\hline
\end{tabular}

0 and the maximum number of informal contact was 9 with an average value of 1.8 which again shows that the average number of students had informal contact with their teachers for less than or exactly two times. The duration of office visit varies from 0 minutes (minimum) to 40 minutes (maximum); however the average numbers of students do not meet their teachers at the office for more than 5 minutes. Similarly, the length of informal contact by students with their teachers varies from 0 minutes (minimum) to 90 minutes (maximum), however the average number of students have informal chats with their teachers for not more than 11 minutes. The discussion of the course work during office visits varies from 0 minutes (minimum) to 100 minutes (maximum) whereas the average number of students have $25 \%$ of their discussion about the course work during office visits. The discussion of course work during informal contact varies from 0 (minimum) to $92 \%$ (maximum) whereas the average number of students have only $24 \%$ of their discussion about the course work during informal contract with their teachers. The discussion of personal prob- 
lems during the office visits varies from $0 \%$ to $80 \%$, however the average number of students have only $4 \%$ of their discussion related to personal problems during office visits. The discussion of personal problems during informal contact varies from $0 \%$ to $90 \%$ with an average score of $9 \%$ which shows that personal problems are discussed more during the informal contact as compared to the discussions during office visits. Socialization during office visits ranges from $0 \%$ to $100 \%$ with an average number of students having scored only $22 \%$ during office visits. Similarly socialization during informal contact also ranges from $0 \%$ to $100 \%$ with average number of students experiencing it $25 \%$ during informal contact, which shows that socialization in most of the cases takes place during the informal contacts as compared to office visits. Students' satisfaction is measured on a seven point Likert scale with value 1 representing minimum satisfaction and value 7 as the higher level of satisfaction. It

Table 4: Correlations (Overall Variables)

\begin{tabular}{|c|c|c|c|c|c|c|}
\hline & & OCC & Motivation & Trust & Verbal & NVerbal \\
\hline OCC & $\begin{array}{c}\text { Pearson } \\
\text { Correlation }\end{array}$ & 1 & $.796^{* *}$ & $.884^{* *}$ & $.946^{* *}$ & .209 \\
\hline Motivation & $\begin{array}{c}\text { Pearson } \\
\text { Correlation }\end{array}$ & $.796^{* *}$ & 1 & $.939^{* *}$ & $.656^{* *}$ &. .072 \\
\hline Trust & $\begin{array}{c}\text { Pearson } \\
\text { Correlation }\end{array}$ & $.884^{* *}$ & $.939^{* *}$ & 1 & $.821^{* *}$ & .256 \\
\hline Verbal & $\begin{array}{c}\text { Pearson } \\
\text { Correlation }\end{array}$ & $.946^{* *}$ & $.656^{* *}$ & $.821^{* *}$ & 1 & $.449^{*}$ \\
\hline NVerbal & $\begin{array}{c}\text { Pearson } \\
\text { Correlation }\end{array}$ & .209 &. .072 & .256 & $.449^{*}$ & 1 \\
\hline
\end{tabular}

**. Correlation is significant at the 0.01 level (2-tailed).

*. Correlation is significant at the 0.05 level (2-tailed).

is interesting to note that more than ninety percent of female students in the selected sample never visited their teacher at the office. The average score of 5 shows that the average number of students do not have their satisfaction at the highest level. Table 4 provides correlation information about the variables.

Table 4 shows correlation of out-of-class-communication with motivation, trust, verbal and non-verbal immediacy at $1 \%$ and $5 \%$ levels of significance. The results shows a significant positive correlation between out-of-class-communication and motivation $(\mathrm{r}=.79$ at $5 \%$ level of significance), which means that a positive change will take place in one variable if the other variable changes positively as well and vice versa, therefore motivation increases with the increase in out-of-class-communication between the students and teachers. Similarly, with increase in out-of-class-communication, the 
motivational level of students also increases. Out-of-class-communication and trust are also positively correlated ( $r=.88$ at $5 \%$ level of significance), which implies that the level of trust in the instructor increases with an increase in out-of-class-communication. Similarly verbal immediacy behavior of the teacher is also positively correlated $(\mathrm{r}=$ .94 at $5 \%$ level of significance) with out-of-class-communication, which means that a positive change in verbal immediacy leads to a positive change in out-of-class-com-

Table 5: Correlations (Aspects of OCC \& Other Variables)

\begin{tabular}{|c|c|c|c|c|}
\hline Aspects of OCC & Motivation & Trust & $\begin{array}{l}\text { Verbal Imme- } \\
\text { diacy }\end{array}$ & $\begin{array}{l}\text { Non-verbal } \\
\text { Immediacy }\end{array}$ \\
\hline $\begin{array}{l}\text { Frequency of } \\
\text { office visits }\end{array}$ & $.619^{* *}$ & $.596^{* *}$ & $.734^{* *}$ & -.197 \\
\hline $\begin{array}{c}\text { Frequency of } \\
\text { informal contact }\end{array}$ & $.692^{* *}$ & $.703^{* *}$ & $.821^{* *}$ & -.073 \\
\hline $\begin{array}{l}\text { Length of office } \\
\text { visits }\end{array}$ & $.578^{* *}$ & $.572^{* *}$ & $.665^{* *}$ & -177 \\
\hline $\begin{array}{c}\text { Length of infor- } \\
\text { mal contact }\end{array}$ & $.524^{*}$ & $.739^{* *}$ & $.625^{* *}$ & $.756^{* *}$ \\
\hline $\begin{array}{c}\text { Discuss course } \\
\text { work during } \\
\text { office visits }\end{array}$ & $.618^{* *}$ & $.595^{* *}$ & $.739^{* *}$ &. .201 \\
\hline $\begin{array}{c}\text { Discuss course } \\
\text { work during } \\
\text { informal contact }\end{array}$ & $.794^{* *}$ & $.874^{* *}$ & $.939^{* *}$ & .196 \\
\hline $\begin{array}{c}\text { Discuss personal } \\
\text { problems during } \\
\text { office visits }\end{array}$ & .673 & .562 & .546 & -.173 \\
\hline $\begin{array}{l}\text { Discuss personal } \\
\text { problems during } \\
\text { informal contact }\end{array}$ & $.460^{*}$ & $.670^{* *}$ & $.544^{*}$ & $.784^{* *}$ \\
\hline $\begin{array}{c}\text { Socialize during } \\
\text { office visits }\end{array}$ & $.619^{* *}$ & $.595^{* *}$ & $.737^{* *}$ & -.200 \\
\hline $\begin{array}{l}\text { Socialize during } \\
\text { informal contact }\end{array}$ & $.725^{* *}$ & $.759^{* *}$ & $.865^{\text {** }}$ & .005 \\
\hline $\begin{array}{l}\text { Student Satisfac- } \\
\text { tion }\end{array}$ & $.606^{* *}$ & $.586^{* *}$ & $.715^{* *}$ & .193 \\
\hline
\end{tabular}

**. Correlation is significant at the 0.01 level (2-tailed).

*. Correlation is significant at the 0.05 level (2-tailed). 
munication and vice versa. Regarding non-verbal immediacy, the results show no significant relationship between out-of-class-communication and non-verbal immediacy. Table 5 shows all aspects of out-of-class-communication and their relationship with motivation, trust, and verbal and non-verbal immediacy.

Motivation, trust, and verbal immediacy have strong correlation with out-of-class-communication as evident from Table 5. However, non-verbal immediacy also has significant correlation with some of the aspects of out-of-class-communication ( 2 out of 11 ). The above table shows a significant positive correlation between non-verbal immediacy and length of informal contact $(r=.75)$, and between non-verbal

Table 6: Least Squares

\begin{tabular}{|c|c|c|c|c|}
\hline & Coefficient & Std. Error & $\mathrm{t}$-Statistic & Prob. \\
\hline $\mathrm{C}(1)$ & 8.419924 & 0.116295 & 72.40164 & 0.0000 \\
\hline $\mathrm{C}(2)$ & 0.018497 & 0.002320 & -7.971536 & 0.0000 \\
\hline $\mathrm{C}(3)$ & 0.092444 & 0.027329 & 3.382644 & 0.0008 \\
\hline $\mathrm{C}(4)$ & 0.059266 & 0.049301 & 1.202126 & 0.2299 \\
\hline $\mathrm{C}(5)$ & 9.584112 & 0.109880 & 87.22313 & 0.0000 \\
\hline $\mathrm{C}(6)$ & 0.011580 & 0.002192 & -5.281695 & 0.0000 \\
\hline $\mathrm{C}(7)$ & 0.022075 & 0.025822 & 0.854913 & 0.3930 \\
\hline $\mathrm{C}(8)$ & 0.103192 & 0.046582 & 2.215264 & 0.0272 \\
\hline \multicolumn{5}{|c|}{ Determinant residual covariance 0.015397} \\
\hline R-squared & 0.231433 & $\begin{array}{l}\text { Mean depen- } \\
\text { dent var }\end{array}$ & \multicolumn{2}{|c|}{7.805914} \\
\hline Adjusted R-squared & 0.222061 & $\begin{array}{l}\text { S.D. dependent } \\
\text { var }\end{array}$ & \multicolumn{2}{|c|}{0.430691} \\
\hline S.E. of regression & 0.379874 & $\begin{array}{l}\text { Sum squared } \\
\text { resid }\end{array}$ & \multicolumn{2}{|c|}{35.49878} \\
\hline Durbin-Watson stat & 1.761962 & & & \\
\hline \multicolumn{5}{|c|}{ Equation: MOTIV $=\mathrm{C}(5)+\mathrm{C}(6)^{*} \mathrm{NON} \_\mathrm{VERB}+\mathrm{C}(7)^{*} \mathrm{VERB}+\mathrm{C}(8)^{*} \mathrm{OCC}$} \\
\hline \multicolumn{5}{|c|}{ Observations: 204} \\
\hline R-squared & 0.114373 & $\begin{array}{l}\text { Mean depen- } \\
\text { dent var }\end{array}$ & \multicolumn{2}{|c|}{9.157023} \\
\hline Adjusted R-squared & 0.103573 & $\begin{array}{l}\text { S.D. dependent } \\
\text { var }\end{array}$ & \multicolumn{2}{|c|}{0.379090} \\
\hline S.E. of regression & 0.358922 & $\begin{array}{l}\text { Sum squared } \\
\text { resid }\end{array}$ & \multicolumn{2}{|c|}{31.69088} \\
\hline Durbin-Watson stat & 1.657855 & & & \\
\hline
\end{tabular}


Table 7: Seemingly Unrelated Regression

\begin{tabular}{|c|c|c|c|c|}
\hline & Coefficient & Std. Error & t-Statistic & Prob. \\
\hline $\mathrm{C}(1)$ & 8.419924 & 0.115361 & 72.98790 & 0.0000 \\
\hline $\mathrm{C}(2)$ & 0.018497 & 0.002302 & -8.036084 & 0.0000 \\
\hline$C(3)$ & 0.092444 & 0.027109 & 3.410034 & 0.0007 \\
\hline $\mathrm{C}(4)$ & 0.059266 & 0.048905 & 1.211860 & 0.2261 \\
\hline $\mathrm{C}(5)$ & 9.584112 & 0.108998 & 87.92940 & 0.0000 \\
\hline $\mathrm{C}(6)$ & 0.011580 & 0.002175 & -5.324462 & 0.0000 \\
\hline$C(7)$ & 0.022075 & 0.025614 & 0.861836 & 0.3892 \\
\hline $\mathrm{C}(8)$ & 0.103192 & 0.046208 & 2.233202 & 0.0260 \\
\hline \multicolumn{3}{|c|}{ Determinant residual covariance } & \multicolumn{2}{|l|}{0.015397} \\
\hline \multicolumn{5}{|c|}{ Equation: TRUST $=\mathrm{C}(1)+\mathrm{C}(2)^{*} \mathrm{NON} \_\mathrm{VERB}+\mathrm{C}(3)^{*} \mathrm{VERB}+\mathrm{C}(4)^{*} \mathrm{OCC}$} \\
\hline \multicolumn{5}{|c|}{ Observations: 204} \\
\hline R-squared & 0.231433 & $\begin{array}{l}\text { Mean depen- } \\
\text { dent var }\end{array}$ & \multicolumn{2}{|c|}{7.805914} \\
\hline Adjusted R-squared & 0.222061 & $\begin{array}{l}\text { S.D. dependent } \\
\text { var }\end{array}$ & \multicolumn{2}{|c|}{0.430691} \\
\hline S.E. of regression & 0.379874 & $\begin{array}{l}\text { Sum squared } \\
\text { resid }\end{array}$ & \multicolumn{2}{|c|}{35.49878} \\
\hline Durbin-Watson stat & 1.761962 & & & \\
\hline \multicolumn{5}{|c|}{ Equation: MOTIV $=\mathrm{C}(5)+\mathrm{C}(6)^{*} \mathrm{NON} \_\mathrm{VERB}+\mathrm{C}(7)^{*} \mathrm{VERB}+\mathrm{C}(8)^{*} \mathrm{OCC}$} \\
\hline \multicolumn{5}{|c|}{ Observations: 204} \\
\hline R-squared & 0.114373 & $\begin{array}{l}\text { Mean depen- } \\
\text { dent var }\end{array}$ & \multicolumn{2}{|c|}{9.157023} \\
\hline Adjusted R-squared & 0.103573 & $\begin{array}{l}\text { S.D. dependent } \\
\text { var }\end{array}$ & \multicolumn{2}{|c|}{0.379090} \\
\hline S.E. of regression & 0.358922 & $\begin{array}{l}\text { Sum squared } \\
\text { resid }\end{array}$ & \multicolumn{2}{|c|}{31.69088} \\
\hline Durbin-Watson stat & 1.657855 & & & \\
\hline
\end{tabular}

immediacy and discussion of personal problems during informal contact $(\mathrm{r}=.78)$. This implies that greater the non-verbal immediacy between the student and teacher, greater is the length of informal contact. Similarly, greater the non-verbal immediacy, more is the discussion of personal problems during informal contact. Table 6 and Table 7 present the system of equations used for empirical analysis. 
Results from the empirical analysis shows,

$$
\begin{aligned}
& \text { Trust }=8.4+0.02 \text { non_verb }+0.92 \text { verb }+0.06 o c c+\varepsilon_{1} \\
& \text { Motivation }=9.5+0.01 \text { non_verb }+0.02 \text { verb }+0.10 \text { occ }+\varepsilon_{2}
\end{aligned}
$$

As earlier mentioned the study used system of equations for empirical analysis. This system of equation contains two equations that are estimated as seemingly unrelated model for which the researchers have taken two dependent variables, i.e. trust and motivation; whereas, independent variables are non-verbal, verbal, and out-of-class-communication (OCC). Our empirical results show that non-verbal communication, verbal communication, and OCC positively affect trust and motivation of the students.

Findings from the study reveal similarities with similar studies conducted in a different contextual setting (Jaasma \& Koper, 1999; Dobransky \& Frymier, 2004; Pogue \& Ahyun, 2006; Jones, 2008)

\section{Conclusion}

Results from data analysis have given important insights about the relationship of variables and their proposed impact on the student retention within the higher education institutions. As it is observed that verbal and non-verbal immediacy behaviors have a strong correlation with students' trust in their teachers and their level of motivation, it becomes imperative for teachers to focus on their verbal and non-verbal behavior which not only helps in the student retention and their academic performance, but also brings benefits to teachers in the form of better evaluations by their students.

Further, out-of-class-communication, verbal, and non-verbal immediacy are found to have strong positive relationship with student motivation and their trust in teachers. Therefore, in addition to retaining students and having healthy evaluations, another effective strategy for the teachers is to engage themselves more in out-of-class-communication with their students. This would not only help in retaining students but also help in eliminating anxiety and apprehension among the students. More open and informal communication as obvious from the results encourages students to discuss their personal issues with their teachers. Students who spend more time with their teachers informally thus feel more valued, confident, counseled, and more satisfied than those who do not engage in out-of-class-communication with their teachers.

It is interesting to note that more than ninety percent of female students in the selected sample never visited their teacher at the office. Since we live in a highly male dominated society and most of the teachers in higher education institutes at Khyber 
Pakhtunkhwa are male, one explanation to this may be that the female students are reluctant to meet their teachers at the office. In fact, it would be interesting to carry out a study trying to find out if the correlation between out-of-class-communication and students' motivation, trust, and teacher's immediacy will have the same results for a sample comprised of only female students.

Future research could focus on understanding the phenomena of how OCC could be improved between the teacher and students, given the fact that OCC helps in student retention and motivation. Further, there are various types of students ranging from studious to a non-studious type therefore, research could also be conducted in order to explore as to what type of students actually engage in OCC and for what reasons would they engage in OCC.

\section{References}

Aylor, B., \& Oppliger, P. (2003). Out-of-class communication and student perceptions of instructor humor orientation and socio-communicative style. Communication Education, 52(2), 122-134.

Christophel, D. M. (1990). The relationships among teacher immediacy behaviors, student motivation, and learning. Communication Education, 39(4), 323-340.

Cotten, S. R., \& Wilson, B. (2006). Student-faculty interactions: Dynamics and determinants. Higher Education, 51(4), 487-519.

Dallimore, E. J. (1995, November). Defining "quality" student-faculty interaction: A necessary step in understanding the student attrition equation. Paper presented at the annual meeting of the Speech Communication Association, San Antonio, TX.

Dobransky, N. D., \& Frymier, A. B. (2004). Developing teacher student relationships through out of class communication. Communication Quarterly, 52(3), 211-223.

Fusani, D. S. (1994). "Extra-class” communication: Frequency, immediacy, self-disclosure, and satisfaction in student-faculty interaction outside the classroom. Journal of Applied Communication Research, $22,232-2$.

Gorham, J. (1988). The relationship between verbal teacher immediacy behaviors and student learning. Communication Education, 37(1), 40-53.

Jaasma, M. A., \& Koper, R. J. (1999). The relationship of student-faculty out-of-class communication to instructor immediacy and trust and to student motivation. Communication Education, 48(1), 41-47.

Jones, A. C. (2008). The effects of out-of-class support on student satisfaction and motivation to learn. Communication Education, 57(3), 373-388.

Kuh, G. D. (1995). The other curriculum: Out-of-class experiences associated with student learning and personal development. The Journal of Higher Education, 66(2), 123-155 
Lamport, M. A. (1993). Student-faculty interaction and the effect on college student outcomes: A review of the literature. Adolescence, 112, 971-990.

Lau, L. K. (2003). Institutional factors affecting student retention. Education, 124(1), 126-136.

McCroskey, J. C., Sallinen, A., Fayer, J. M., Richmond, V. P., \& Barraclough, R. A. (1996). A cross-cultural and multi-behavioral analysis of the relationship between nonverbal immediacy and teacher evaluation. Communication Education, 45, 281-291.

Milem, J. F., \& Berger, J. B. (1997). A modified model of college student persistence: Exploring the relationship between Astin's theory of involvement and Tinto's theory of student departure. Journal of College Student Development, 38(4), 387-400.

Myers, S. A., Edwards, C., Wahl, S. T., \& Martin, M. M. (2007). The relationship between perceived instructor aggressive communication and college student involvement. Communication Education, 56(4), 495-508.

Myers, S. A., \& Knox, R. L. (2001). The relationship between college student information-seeking behaviors and perceived instructor verbal behaviors. Communication Education, 50(4), 343-356.

Nadler, M. K., \& Nadler, L. B. (1995). The roles of empathy, credibility, and sex in out of class communication between faculty and students. Paper presented at the annual meeting of the Speech Communication Association, San Antonio, TX.

Nadler, M. K., \& Nadler, L. B. (2000). Out of class communication between faculty and students: A faculty perspective. Communication Studies, 51(2), 176-188.

Nora, A., \& Cabrera, A. F. (1996). The role of perceptions of prejudice and discrimination on the adjustment of minority students to college. The Journal of Higher Education, 67(2), 119- 148.

Pascarella, E. T., \& Terenzini, P. T. (1991). How college affects students: Findings and insights from twenty years of research. San Francisco, CA: Jossey-Bass

Pascarella, E. T., \& Terenzini, P. T. (1978). Student-faculty informal relationships and freshman year educational outcomes. The Joumal of Educational Research, 71(4), 183-189.

Pascarella, E. T., \& Terenzini, P. T. (1979). Student-faculty informal contact and college persistence: A further investigation. The Journal of Educational Research, 72(4), 214-218.

Pike, G. R., Schroeder, C. C., \& Berry, T. R. (1997). Enhancing the educational impact of residence halls: The relationship between residential learning communities and first-year college experiences and persistence. Journal of College Student Development, 38, 609- 621.

Pogue, L. L., \& Ahyun, K. (2006). The effect of teacher nonverbal immediacy and credibility on student motivation and affective learning. Communication Education, 55(3), 331-344.

Richmond, V. P. (1990). Communication in the classroom: Power and motivation. Communication Education, 39(3), 181-195. 
Rubin, R. B., Palmgreen, P., \& Sypher, H. E. (Eds.). (1994). Communication research measures: A sourcebook. New York: The Guilford Press.

Terenzini, P. T., Pascarella, E. T., \& Blimling, G. S. (1996). Students' out-of-class experiences and their influence on learning and cognitive development: A literature review. Journal of College Student Development, 40(5), 610-623.

Theophilides, C., \& Terenzini, P. T. (1981). The relation between nonclassroom contact with faculty and students' perceptions of instructional quality. Research in Higher Education, 15(3), 255-269.

Thomas, L. (2002). Student retention in higher education: the role of institutional habitus. Journal of Education Policy, 17(4), 423-442.

Wheeless, L. R., \& Grotz, J. (1977). The measurement of trust and its relationship to self- disclosure. Human Communication Research, 3(3), 250-257.

Wilson, R. C., Woods, L., \& Gaff, J. G. (1974). Social-psychological accessibility and faculty- student interaction beyond the classroom. Sociology of Education, 47(1), 74-92.

Witt, P. L., Schrodt, P., \& Turman, P. D. (2010). Connections Conducive to Classroom Learning. The SAGE Handbook of Communication and Instruction, 201.

\section{Appendix}

\section{Questionnaire}

Age: Gender: M/F

These items are concerned about how you feel about the class you took immediately preceding this class. Please circle the number towards wither word which best represents your feelings. Note that in some cases the most positive score is " 1 " while in other cases it is "?".

\begin{tabular}{|c|c|c|c|c|c|c|c|c|}
\hline $\begin{array}{c}\text { Unen- } \\
\text { thused }\end{array}$ & 1 & 2 & 3 & 4 & 5 & 6 & 7 & Enthused \\
\hline $\begin{array}{c}\text { Dreading } \\
\text { it }\end{array}$ & 1 & 2 & 3 & 4 & 5 & 6 & 7 & $\begin{array}{c}\text { Looking } \\
\text { forward }\end{array}$ \\
\hline $\begin{array}{c}\text { Not fasci- } \\
\text { nated }\end{array}$ & 1 & 2 & 3 & 4 & 5 & 6 & 7 & Fascinated \\
\hline $\begin{array}{c}\text { Interest- } \\
\text { ed }\end{array}$ & 1 & 2 & 3 & 4 & 5 & 6 & 7 & Uninterested \\
\hline $\begin{array}{c}\text { Unchal- } \\
\text { lenged }\end{array}$ & 1 & 2 & 3 & 4 & 5 & 6 & 7 & Challenged \\
\hline $\begin{array}{c}\text { Motivat- } \\
\text { ed }\end{array}$ & 1 & 2 & 3 & 4 & 5 & 6 & 7 & Unmotivated \\
\hline
\end{tabular}




\begin{tabular}{|c|c|c|c|c|c|c|c|c|}
\hline $\begin{array}{c}\text { Unre- } \\
\text { freshing }\end{array}$ & 1 & 2 & 3 & 4 & 5 & 6 & 7 & Refreshing \\
\hline $\begin{array}{c}\text { Not Stim- } \\
\text { ulated }\end{array}$ & 1 & 2 & 3 & 4 & 5 & 6 & 7 & Stimulated \\
\hline Excited & 1 & 2 & 3 & 4 & 5 & 6 & 7 & Not Excited \\
\hline Useful & 1 & 2 & 3 & 4 & 5 & 6 & 7 & Useless \\
\hline Helpful & 1 & 2 & 3 & 4 & 5 & 6 & 7 & Harmful \\
\hline $\begin{array}{c}\text { Import- } \\
\text { ant }\end{array}$ & 1 & 2 & 3 & 4 & 5 & 6 & 7 & Unimportant \\
\hline Inspired & 1 & 2 & 3 & 4 & 5 & 6 & 7 & Uninspired \\
\hline Aroused & 1 & 2 & 3 & 4 & 5 & 6 & 7 & Unaroused \\
\hline Involved & 1 & 2 & 3 & 4 & 5 & 6 & 7 & Uninvolved \\
\hline
\end{tabular}

Below items are concerned about how you feel about the teacher you took class with just before this one. Please circle the number towards wither word which best represents your feelings.

\begin{tabular}{|c|c|c|c|c|c|c|c|c|}
\hline Trustworthy & 1 & 2 & 3 & 4 & 5 & 6 & 7 & $\begin{array}{l}\text { Untrust- } \\
\text { worthy }\end{array}$ \\
\hline Trustful & 1 & 2 & 3 & 4 & 5 & 6 & 7 & Distrustful \\
\hline Confidential & 1 & 2 & 3 & 4 & 5 & 6 & 7 & Divulging \\
\hline Benevolent & 1 & 2 & 3 & 4 & 5 & 6 & 7 & Exploitive \\
\hline Safe & 1 & 2 & 3 & 4 & 5 & 6 & 7 & Dangerous \\
\hline Frank & 1 & 2 & 3 & 4 & 5 & 6 & 7 & Deceptive \\
\hline $\begin{array}{c}\begin{array}{c}\text { Not Deceit- } \\
\text { ful }\end{array} \\
\end{array}$ & 1 & 2 & 3 & 4 & 5 & 6 & 7 & Deceitful \\
\hline $\begin{array}{l}\text { Straight } \\
\text { forward }\end{array}$ & 1 & 2 & 3 & 4 & 5 & 6 & 7 & Tricky \\
\hline Respectful & 1 & 2 & 3 & 4 & 5 & 6 & 7 & $\begin{array}{c}\text { Disrespect- } \\
\text { ful }\end{array}$ \\
\hline Considerate & 1 & 2 & 3 & 4 & 5 & 6 & 7 & $\begin{array}{c}\text { Inconsid- } \\
\text { erate }\end{array}$ \\
\hline Honest & 1 & 2 & 3 & 4 & 5 & 6 & 7 & Dishonest \\
\hline Reliable & 1 & 2 & 3 & 4 & 5 & 6 & 7 & Unreliable \\
\hline Faithful & 1 & 2 & 3 & 4 & 5 & 6 & 7 & Unfaithful \\
\hline Sincere & 1 & 2 & 3 & 4 & 5 & 6 & 7 & Insincere \\
\hline Careful & 1 & 2 & 3 & 4 & 5 & 6 & 7 & Careless \\
\hline
\end{tabular}


Given below are some of the aspects of Out-of-class-communication (OCC), please indicate your experience with the following items on the range given for each item.

Frequency of office visits (In Number)

Frequency of informal contact (In Number)

Length of office visits (In Minutes)

Length of informal contacts (In Minutes)

Discuss course work during office visits (In Percentage)

Discuss course work during informal contact (In Percentage)

Discuss personal problems during office visits (In Percentage)

Discuss personal problems during informal contact (In Percentage)

Socialize during office visits (In Percentage)

Socialize during informal contact (In Percentage)

Student satisfaction $\left(\begin{array}{lllllll}1 & 2 & 3 & 4 & 5 & 6 & 7\end{array}\right)$

Below are a series of descriptions of things some teacher have been observed doing or saying in some classes. Please respond to the questions in terms of the class you took immediately preceding this class or the class you are in now. For each item, circle the number 0-4 which indicates the behavior of the teacher in that class.

\footnotetext{
Scale: $\quad$ Never $=0 \quad$ Rarely $=1 \quad$ Occasionally $=2 \quad$ Often $=$ 3 Very Often $=4$

Verbal Items:
}

1. Uses personal examples or talks about experiences she/he has had outside of class.

2. Asks questions or encourages students to talk.

3. Gets into discussions based on something a student brings up even when this doesn't seem to be part of his/her lecture plan.

4. Uses humor in class. 
5. Addresses students by name.

6. Addresses me by name.

7. Gets into conversations with individual students before or after class.

8. Has initiated conversations with me before, after or outside of class.

9. Refers to class as "my" class or what "I" am doing.

10. Refers to class as "our" class or what "we" are doing.

11. Provides feedback on my individual work though comments on papers, oral discussions, etc.

12. Calls on students to answer questions even if they have no indicated that they want to talk.

13. Asks how students feel about an assignment, due date or discussion topic.

14. Invites students to telephone or meet with him/her outside of class if they have questions or want to discuss something.

15. Asks questions that have specific, correct answers.

16. Asks questions that solicit viewpoints or opinions.

17. Praises student's work, actions or comments.

18. Criticizes or points out faults in student's work, actions or comments.

19. Will have discussions about things unrelated to class with individual students or with the class as a whole.

20. Is addressed by his/her first name by the students.

Nonverbal Items:

1. Sits behind desk while teaching.

2. Gestures while talking to the class.

3. Uses monotone/ dull voice when talking to the class.

4. Looks at the class while talking.

5. Smiles at the class while talking. 
6. Has a very tense body position while talking to the class.

7. Touches students in the class.

8. Moves around the classroom while teaching.

9. Sits on the desk or in a chair while teaching.

10. Looks at board or notes while talking to the class.

11. Stands behind podium or desk while teaching.

12. Has a very relaxed body position while talking to the class.

13. Smiles at individual students in the class.

14. Uses a variety of vocal expressions when talking to the class. 